\title{
Evolution of the Monetary System of the Ottoman Empire
}

\author{
Validova A.F. \\ Kazan Federal University, Institute of Management, Economics and Finance, Kazan, 420008, Russia
}

Email: avalidova@gmail.com

\section{Doi:10.5901/mjss.2014.v5n28p71}

\begin{abstract}
This paper investigates the ancient forms of money in the Ottoman empire, provides money terminology and discusses the history of the monetary system of Turkey. It analyses the problems that arose during the period of silver standard and further during bimetallic monetary system. Gold was the most important medium of long distance trade, whereas silver was more often used for local and smaller transactions. The problem of debasement of money is described and analysis of this phenomenon is given in the paper. Economic history of the Ottoman Empire is viewed from the perspective of the evolution of its money.
\end{abstract}

Keywords: money, currency, monetary system, coinage, bimetallic standard

\section{Introduction}

Investigation of the ancient forms of money arose the wide interest of scholars by the fact that currencies represent the development of the trade relations of the states. The research of the traditions of the money circulation, money terminology contributes to better understanding of the cultural, social and economic development of the country. Moreover, establishment of the money coinage indicated the country's sovereignty.

The history of the monetary system of Turkey goes back to the foundation of the Ottoman Empire.The Turkish state originated in the province of Anatolia which was awarded to one of the turki tribe leader Ertu?rul by a Seljuk Sultan for his support in the battle. During the period of disintegration of the Seljuk Sultanate of R?m it was separated to different principalities or beyliks, one of those beyliks became the independent state and was named after Osman I, son of Ertu?rul. By the end of the 13 - beginning of the 14 century Osman's beylik extended the frontiers of the Ottoman settlements by raiding Bysantine territories and after moving the capital of the state to Bursa in 1326 the foundation of the new dominant state was complete. It can also be demonstrated by the fact that in 1327 Orhan bey made arrangements to mint the first Ottoman silver coin - "akce". Coins circulated before that time were coins of Seljuk mint, which considered to be of reliable value. According to historian Vasyf, throughout the $14^{\text {th }}$ century during the times of Osman's government different types of foreign coins continued to be used in the beylik: Seljuk dirhems, Indian, Persian and Arab, Bysantine coins as well as some European currency like Venice ducats which were widely spread [1]. It was reasonable and could be explained by the commercial needs and geographical location of Anatolia as trade commodities from India, China, Iran were delivered to the Anatolian ports and then were transported to Bysantine Empire and many European countries.

Mentioned above first Ottoman coin minted by Orhan was based on Ihanide issues, it weighed 6 carats and contained of $90 \%$ of fine silver and had a legend "Son of Osman, Orhan. Minted in Bursa" made in Arabic script. It should be noted that some sources show that Orhan minted his coins in 1328, but according to the works of Hairullah Efendi coins have been minted both in 1327 when Orhan was awarded the title of Bey and in 1328 [2]. It is also important that sultan Orhan also have been minted copper species which like the coins of his predecessors had no writings on them.

\section{Theory}

The conclusion that can be made is that throughout 14-16 centuries Ottoman money evolved from the adoption of the ancient Seljuk coins, as the sultanate's monetary sphere of influence lasted longer after its demise, to the introduction of their own sovereign currency. It should also be underlined that like in many other medieval states in Ottoman Empire the mintage was not restricted by minting officials, so, according to the notes of Florentine merchant and financier Francesco Pegolotti referring to the second half of the $14^{\text {th }}$ century, any trading man who have had silver bullions could have minted species in the Mint [4]. The government, however, regulated the shape, weight and fineness of the currency in circulation because during the metallic standard the metal value of coins was of vital importance. 
Untill Mehmed II came in to power the monetary system of the Ottoman state was based on the silver standard where economic unit of account was a fixed weight of silver. Only in 1453 after the conquest of Constantinople and turning it to the new capital which soon became the political, economic and cultural centre of Ottoman Empire, Mehmed the Conqueror minted the first Turkish golden coin - "altin". This event signified the milestone in the monetary history transition from silver standard to bimetallism.

According to historical sources, $15-16$ centuries were characterised by the significant decline of the weight of silver coin in the Ottoman Empire that has faced the problem of debasement of coinage which reached its apogee in the middle of the 16 century and remained one of the big difficulties in the monetary sphere of the country for several centuries. Debasement was done by public by cutting or scraping off some of the precious metal, consequently, the value of akce gradually decreased over time, causing the inflation. Debasement and shaving off the silver coins finally was one of the reasons of the fact that in 17-18 centuries new coins as a standard of currency were adopted- the silver coin "kurus" (piaster) that over time completely replaced akce, and the subunit of kurus - "para". Meanwhile, huge sultanate court maintenance costs, series of devastating wars, which caused significant rise of military expenditures, led to the budget deficits, fiscal difficulties and economic stagnation of the Ottoman Empire in the 17-18 centuries. Government's efforts to stabilize the monetary system were futile and ambiguous: struggling with the coin debasement mint authorities tried to withdraw debased species from the circulation, melt them down and replace with new golden coins after enhancing their gold content.

These measures caused two kinds of problems: first, higher quality coins were removed from circulation as individuals were motivated to keep them, melt them down and sell the metal for its higher bullion value - this phenomenon, described by Thomas Gresham is known as Gresham's law. Second, coins with the high content of gold had driven out of the country of issue while foreign debased coins flooded the market. But, on the other hand, the issuing authorities themselves from time to time reduced silver or gold content of the coin usually by alloying it with base metal in order to mint more coins out of a given amount of specie and thus finance the public deficits. By the end of the $17^{\text {th }}$ century, for example, silver akce lost its intrinsic value by ten times from its original value so its purchasing power was almost the same like a copper coin had.

\section{Results}

During the $18^{\text {th }}$ century, destabilization of the Ottoman monetary system, resulted from depreciation of the currency and acceleration of the inflation process, undermined the trade in the region and caused the social tension. All kinds of government's measures taken in order to fix the ratio between gold and silver by law and to decree the value of coins by government fiat never succeeded. Consequently, the difficulties, monetary authorities faced during the period of bimetallic standard, which had been practiced in Ottoman Empire for several centuries, can be explained by the unstable monetary system based on the circulation of two metals.

Investigation of the developments in money system during the $19^{\text {th }}$ century, known by historians as a period of the decline of the Ottoman Empire, shows the importance of series reforms in all spheres of economic and political life of the country. During the Tanzimat period (1830-40) significant steps towards modernization and Europeanization of the Ottoman state have been made. Among them there should be mentioned the reforms applied to reorganize the monetary system of the country in order to overcome further depreciation of nation's currency and to clarify the principals of the money circulation to the public.

The monetary reforms are connected with the name of sultan Abd-ul-Mejid, during his reign after analyzing all the attempts government did in the monetary sphere, and all they failures that happened one after another, the reorganization of the Ottoman monetary system took place. This fact in particular gives an explanation why in some Turkish sources the records of the first Turkish gold and silver coins refer to 1843 and 1844. "Edict of metal currency" brought order to the system of species in circulation and introduced the value of gold and silver coins and ratio between two metals. Kuruş which replaced akce, became a silver unit of account, and was joined by gold lira, which from 1844 till 1881, according to the ordinance, was equal to 6.61519 grams pure gold and 99.8292 grams pure silver. Thus, bimetallic standard remained in Ottoman Empire till the 1881, and after all the difficulties it caused, monetary authorities abandoned the effort to fix the exchange rate between two metals and adopted a system of monometallism, with gold as its basic unit of trade. Eventually, decimalized Ottoman Empire gold lira was introduced, while kurus became the subunit of lira, with 100 kurus equal to 1 lira.

By the end of $19^{\text {th }}$ - beginning of the $20^{\text {th }}$ century Ottoman Empire because of increased military expenses was economically devastated, and having difficulties in repaying Ottoman public debt almost lost its economic independence. The failure of the economic structure led to the fall of the Ottoman Empire [6]. In order to finance the military expenses 
and fiscal deficits Ottoman government resorted to issuance of paper money and in 1914, eventually, in conditions of global exchange rate chaos went off the gold standard.

\section{Conclusions}

In 14-16 centuries Ottoman money evolved from the adoption of the ancient Seljuk coins, as the sultanate's monetary sphere of influence lasted longer after its demise, to the introduction of their own sovereign currency.

Throughout history, Ottoman government has been known to create more coinage than their supply of precious metals would allow. The intrinsic value of each individual coin was reduced by replacing some fraction of a coin's precious metal content with a base metal, which allowed the authorities to produce more coins than would otherwise be possible. Debased coins dominated circulation more quickly than reinforced ones, and older coins continued to circulate abroad for a longer time than at home. Therefore, debasement of the money was one of the process, that characterised the monetary system of the Ottoman empire for centures. The results demontsrate Greshem's law phenomenon, which took place in the Ottoman Empire in 16-17 th centures.

Destabilization of the Ottoman monetary system, resulted from depreciation of the currency and acceleration of the inflation process, undermined the trade in the region and caused the social tension.

Analysis of the developments of the monetary system of the last century of the Ottoman Empire emphasises the importance of the monetary reforms, and their influence on the country's economic performance. One of the significant stages of the evolution of the monatary system was the introduction of the paper money.

\section{References}

Ekrem Kolercilic. Osmanli Imparatorlugunda Para. - Ankara, 1958. - S. 6.

Devleti Aliyei Osmaniye tarihi. Cilt 3. S. 65-67.

Enver Ziya Karal. Osmali Tarihi. Cild 6. S. 204.

Friedman Milton. 1989. Working Papers on Economics, E-89-24, The Hoover Institution, Stanford University.

Halil Inalcik. 1960. Bursa and The Commerce of the Levant, Journal of the Economic and Social History of the Levant 3, 131-140.

M. Belin, Ziya Karamursel. Turkiye Iktisadi Tarihi. - S. 108.

Munro John H., 1983. Medieval Monetary Problems: Bimetallism and Bullionism, The Journal of Economic History, Vol. 43, No. 1, The Tasks of Economic History, (Mar., 1983), pp. 294-298.

Pamuk Sevket. A Monetary System of the Ottoman Empire. Cambridge University Press, 2000.

R. Stern, G. Herlt, E. Schultze. Geld, Industrialisierung und Petroleumschätze der Türkei. - Berlin, 1918. - Druck und Verlag von Georg Reimer. - S. 12.

Redish A. Bimetallism An Economic and Historical Analysis. Cambridge University Press, 2006, pp.46-59.

Redish A. The Evolution of the Gold Standard in England. The Journal of Economic History, Vol. 50, No. 4, (Dec., 1990), pp. $789-805$.

Razumovskaya, E.M.,Mishakin, T.S., Popov, M.L., Kucevol, N.G. Medical services during the XXVII world summer universiade 2013 in Kazan. Mediterranean Journal of Social Sciences vol. 5 (18 SPEC. ISSUE), pp. 17-20

Arustamyan, G.,Yegorov, E., Lipsky, S.,Razumovskaya, E.,Gimranova, L. Clinical and economic analysis and its role in healthcare quality management. World Applied Sciences Journal vol. 27 (3), pp. 318-323.

Shaidullin R.N., Safiullin L.N., Gafurov I.R., Safiullin N.Z.. Blended learning: leading modern educational technologies. Procedia - Social and Behavioral Sciences. Vol. 131, pp. 105-110. // 3rd World conference on educational technology researches Turkey 0709.11.2013. 